International Journal of Mechanical Engineering and Technology (IJMET)

Volume 11, Issue 9, September 2020, pp. 38-47, Article ID: IJMET_11_09_005

Available online at https://iaeme.com/Home/issue/IJMET?Volume=11\&Issue=9

ISSN Print: 0976-6340 and ISSN Online: 0976-6359

DOI: https://doi.org/10.34218/IJMET.11.9.2020.005

(C) IAEME Publication

Scope Database Indexed

\title{
COMPARISON OF GHG EMISSIONS BETWEEN ICEV AND BEV BASED ON INDIAN SCENARIO
}

\author{
Nibin Joseph \\ Student, St. Vincent Pallotti School, India \\ Ramesh Joseph \\ Senior Engineer, MicroFocus, India
}

\begin{abstract}
Electric vehicles have been recognized just like a key innovation in decreasing future outflows and energy utilization in the versatility segment. The focal point of this article is to audit and survey the energy effectiveness and the natural effect of battery electric vehicles (BEV), which is the main specialized option available accessible today to vehicles with internal combustion engine (ICEV). Power locally available a vehicle can be given either by a battery or a fuel cell (FCV). In this comparison study of emission difference between the conventional ICEV and BEV it is established that the even at the current state of energy grid mixture, transmission losses and battery manufacturing emissions BEF vehicles generate less GHG emissions per unit distance.
\end{abstract}

This submission is done with respect to Indian conditions where significant portion of the electric power generation is sourced from high GHS emitting sources. Comparative emissions from both ICEV and BEV are presented after considering well to wheel and manufacturing emissions.

Keywords: Mechanics, Elecetrical, Energy, Battery, Vehicles, Greenhousegas, Fuel, Efficiency.

Cite this Article: Nibin Joseph and Ramesh Joseph, Comparison of GHG Emissions between ICEV and BEV based on Indian Scenario. International Journal of Mechanical Engineering and Technology. 11(9), 2020, pp. 38-47.

https://iaeme.com/Home/issue/IJMET?Volume $=11 \&$ Issue $=9$

\section{INTRODUCTION}

Electric vehicles are becoming a critical part of the transportation sector because of their high potential to significantly reduce the Green House Gas (GHG) Emission. Many countries have pledged support to significantly reduce GHG emissions by the year 2030. The transportation sector is one of the major contributors to GHG emission. Electric vehicles can significantly help in reducing GHG emission without curtailing the transportation needs. 
But electric vehicles are also not GHG emission free. There is an alternative line of thought which claim that EVs do not reduce the GHG emission considering the 360 view of emissions from the entire life cycle of EVs and their operation emissions. This study quantitatively evaluates all the emissions from the extraction of fuel to its final dissipation as well as the manufacturing emissions of both Internal Combustion Engine Vehicles (ICEV) and Battery Electric Vehicles (BEV).

In this study the following reference model is considered one from the passenger car segment and the other from Motorized Two Wheeler (MTW) segment.

Table 1 Reference vehicles models and its specifications used in the study

\begin{tabular}{|l|c|c|c|c|}
\hline Vehicle Type & $\begin{array}{c}\text { Battery } \\
\text { capacity(kwh) }\end{array}$ & Range(km) & $\begin{array}{c}\text { Computed } \\
\text { Efficiency(km/kwh) }\end{array}$ & $\begin{array}{c}\text { Gross Vehicle } \\
\text { weight(kg) }\end{array}$ \\
\hline $\begin{array}{l}\text { Tata Tigor EV } \\
\text { (Passenger }\end{array}$ & 21.5 & 213 & 9.9 & 1590 \\
$\begin{array}{l}\text { Car) } \\
\text { Honda Dash } \\
\text { (MTW) }\end{array}$ & 1.344 & 60 & 44.64 & 94 \\
\hline
\end{tabular}

\section{OPERATIONAL EMISSION EFFICIENCY OF ELECTRIC VEHICLES}

Here we consider the operational emissions of electric vehicles (EV) in comparison to the conventional Internal Combustion Engine Vehicles (ICEV ). Given the limitation in distance a BEV can travel, users will use the BEV only if the travel requirement is well within the range of the electric vehicle. A Pluggable Electric Vehicle (PEV)'s utility factor is the fraction of the distance that is met with electrical energy source. In the case of Pluggable Hybrid Electric Vehicles (PHEV) that are driven long distances the utility factor is lower as most of the driven distance is covered with gasoline powered engine operating in Charge Sustaining (CS) mode. On the other hand when the PHEV is used to make short trips utility factor is higher because BEV is fully powered by electric energy from battery, driver does not have an option of running the vehicle in charge sustaining mode. The utility factor for a BEV can provide an indication of how a BEV of similar range would perform, but it is not the best measure of the mileage electrification potential of BEVs. A BEV driver usually chooses to use a substitute vehicle when faced with a very long trip. In most cases, alternative vehicle would be Conventional Vehicle (CV) powered by either gasoline or diesel.

Utility factor also depends on charging opportunities, driving patterns, time availability to recharge at the alternate location etc. The Society of Automotive Engineers J2841 standard[1] sets guidelines for calculating the utility factor of PHEVs. J2821 standard assumes that PHEVs have only one opportunity to charge in a day. Since the characteristics of BEVs are different it poses complex challenge. In the case of BEV if the intended travel distance is not met with BEV range the entire trip is traveled with an alternative vehicle. But in the case of PHEVs it can start with all electric operation and when the battery is depleted it switches to gasoline engine in Charge Sustaining (CS) mode for the remaining distance.

There are some alternative utility factor methods proposed [2].

Since there is no specific study found on the utilization factor in Indian conditions this study approximated the Indian scenario to the data provided in [2]. For the BEVs we modeled the utility factor is taken from Alternative utility factor versus the SAE J2841 standard method for PHEV and BEV application by Elena Paffumi, Michele De Gennaro, Giorgio Martini[2] 
Table 2 Range and utility factor of the reference vehicle

\begin{tabular}{|l|c|c|}
\hline \multicolumn{1}{|c|}{ BEV Model } & Range & UF \\
\hline Tata Tigor EV & 213 & 0.9 \\
\hline Hero Nyx ER & 100 & 0.75 \\
\hline
\end{tabular}

This less than one utility factor conveys that even when we use a fully electric vehicle there is a fossil fuel penalty involved because of the limited range of BEVs. This penalty consequently translates to Green House Gas (GHS) emission penalty. Since BEV cannot replace ICEV in all our travel requirements this operational GHS emission resulting from the use of fully electric vehicle is added to the BEV bucket for comparison purpose.

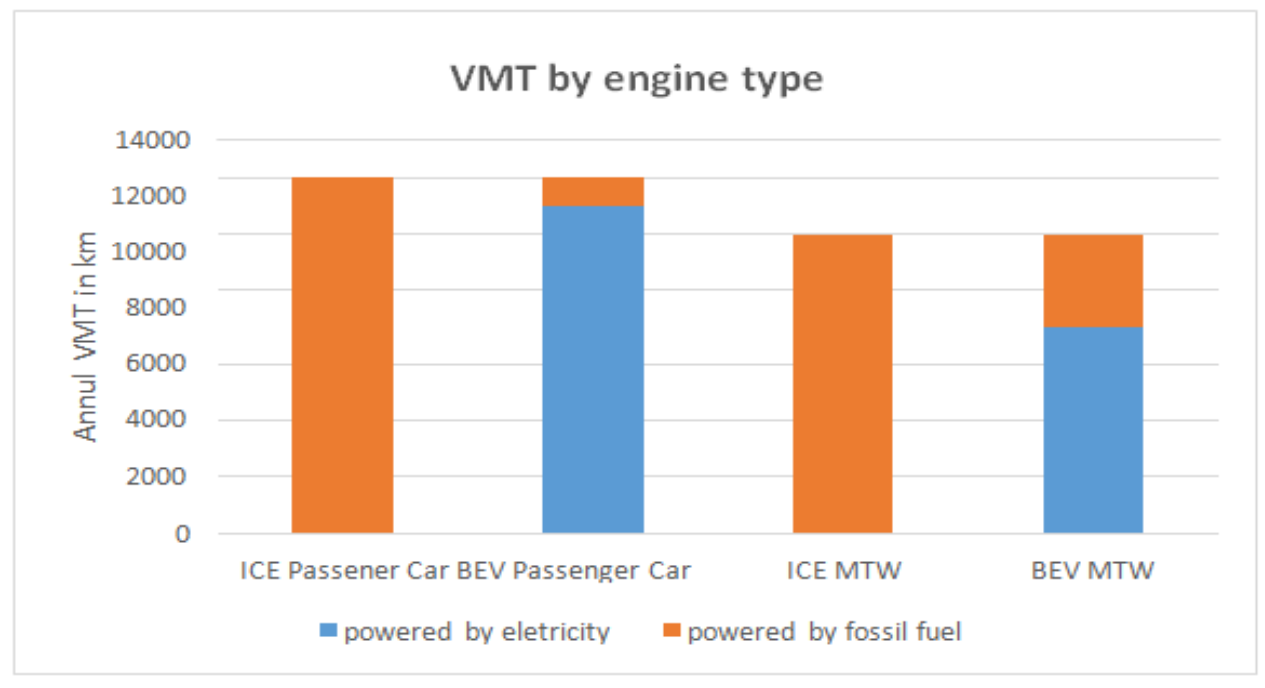

Figure 1 Annul VMT for different classes of vehicle

Based on the running efficiency ( $\mathrm{km} / \mathrm{litre}$ ) and the emissions per unit fuel the GHG emission in $\mathrm{CO}_{2 \mathrm{e}}$ per $\mathrm{km}$ is plotted in figure 2

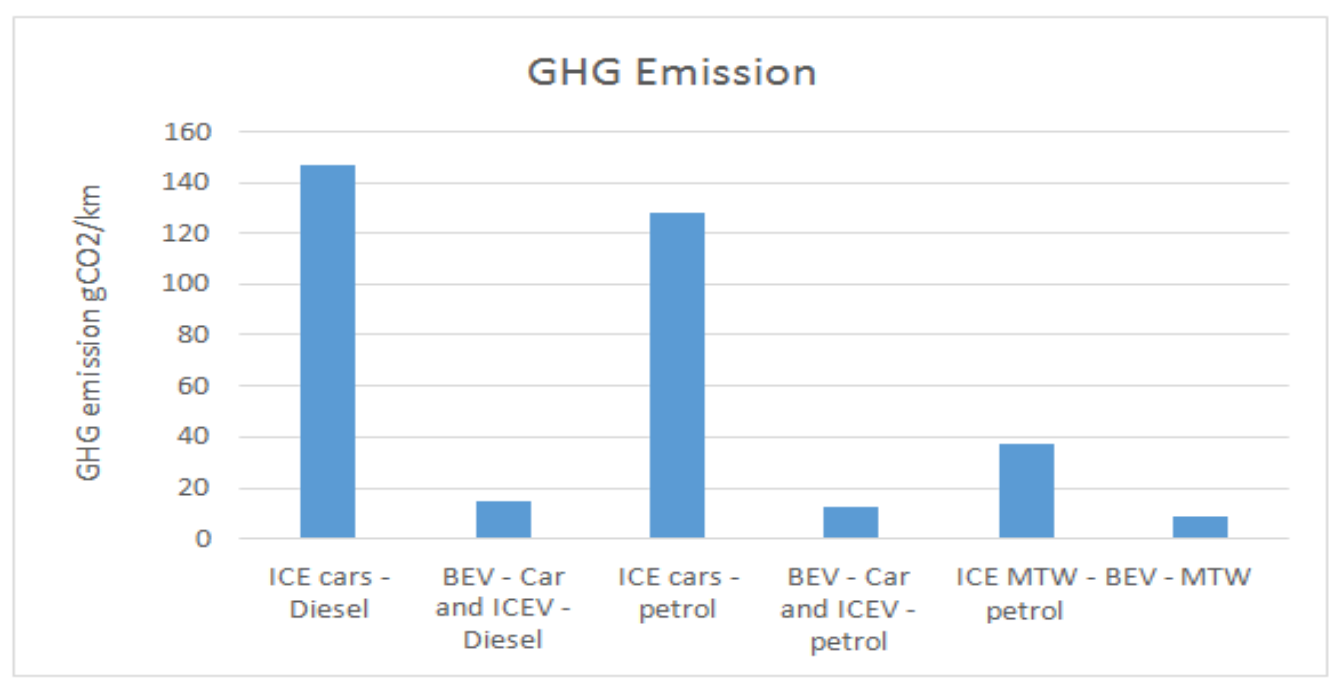

Figure 2 The GHG emission from the operation of the vehicle.

In order to compute and compare the Carbon Dioxide equivalent $\mathrm{CO}_{2 \mathrm{e}}$ emission between an ICEV and BEV the annual Indian vehicle mileage data study from [3] is used. The GHG emission data is computed from Greenhouse Gas Equivalencies calculator [4]. Fuel efficiency data is taken from the government of India fuel specification for 2017-18 to 2021-22[5] 
Based on the average annual vehicle miles traveled (VMT) data taken from [3] VMT for each engine type is plotted in figure 1, after applying the utilization factor. Although BEV operate fully on electric power some ICEV miles are added to BEV data to adequately cover the fraction of the distance one needs to rely on Conventional Vehicle(CV) for his travel needs. This fraction is represented by utility factor.

The GHG emission of BEV can be further reduced by increasing the utility factor. The following can be considered for improving the utilization factor.

- Improve the charging infrastructure at parking places particularly where people have to spent more time like cinema halls, sports stadiums, office parking space, shopping malls etc

- Building more road side parking with charging kiosks. This can also earn revenue for the government

- Plug and play battery design coupled with battery exchange centers can greatly improve the charging time.

\section{ELECTRICITY GENERATION AND MODELING}

Here we consider the GHG emission associated with fuel extraction process, fossil fuel refining, electricity generation, transmission and distribution as well as battery charging. All of the above upstream stages involve GHG emission. The GHG emission study is not complete without considering and incorporating the GHG emissions from the upstream stages.

When estimating emissions from charging an electric vehicle, we use regional average power generation emissions which is averaged over the mix of electric power generation sources. An alternative approach is to consider only the marginal emissions. In marginal emission approach: only emissions from the electric sources operated to meet the additional load of BEV charging over and above the normal load. We used the average model in our study because goal is to find the global warming emissions with the mix of electric sources India is currently using. Also, because of the current low penetration of electric vehicles in India there is no significant change in the grid mix used to meet the demand.

\subsection{Electricity Generation Stage}

GHG emissions from power generation plans depend on the grid mix used in electricity generation.

The following chart shows the energy mix used in India to source electricity[6]. Coal continues to be the major chunk of Indian grid mainly due to the high availability of coal mines. It is also one of the more GHS generating fuel.

Table 3 Power grid mix used in India

\begin{tabular}{|l|c|c|}
\hline \multicolumn{1}{|c|}{ Fuel } & MW & \% of Total \\
\hline Total Thermal & $2,31,421$ & $62.1 \%$ \\
\hline Coal & $1,99,595$ & $53.6 \%$ \\
\hline Lignite & 6,360 & $1.7 \%$ \\
\hline Gas & 24,957 & $6.7 \%$ \\
\hline Diesel & 510 & $0.1 \%$ \\
\hline Hydro (Renewable) & 45,699 & $12.3 \%$ \\
\hline Fuel & MW & $1.8 \%$ \\
\hline Nuclear & 6,780 & $23.8 \%$ \\
\hline RES* (MNRE) & 88,793 & \\
\hline Total & 372,693 & Total \\
\hline
\end{tabular}

* Installed capacity in respect of RES (MNRE) as on 31.08.2020. 
GHG emission for power generation from different fuel sources which is used in the calculation is summarized below

Table 4 Carbon emission from different fuel sources.

\begin{tabular}{|l|c|c|}
\hline \multicolumn{1}{|c|}{ Fuel source } & $\mathbf{C O}_{2}$ Emission in $\mathbf{~ k g} / \mathbf{k w h}$ & Data source \\
\hline Coal & 0.99 & {$[8],[9]$} \\
\hline Gas & 0.46 & $[8]],[9]$ \\
\hline Lignite & 1.36 & {$[8]$} \\
\hline Naphta & 0.56 & {$[8]$} \\
\hline Oil & 0.64 & {$[8]$} \\
\hline
\end{tabular}

\subsection{Emission from Coal Mining}

The coalification produces a lot of methane. Amount of methane produced depends on the depth from which coal is mined. It also depend on the type of coal mined. In India $87 \%$ of the coal production is from opencast mining.

$\mathrm{CH}_{4}$ emission $=\left(\right.$ Surface mining emission of $\mathrm{CH}_{4}+$ Post mining $\mathrm{CH}_{4}$ emission $) \times$ coal mining in tones $\mathrm{CO}_{2}$ equivalent emission $=\mathrm{CH}_{4}$ emission from mining $\mathrm{x}$ Global Warming potential

$\mathrm{CO}_{2}$ equivalent emission is calculated as $0.02 \mathrm{~kg} / \mathrm{kwh}[9]$

\subsection{Emission from Natural Gas Mining}

Emission from production of natural gas arise due to flaring of unusable natural gas. The $\mathrm{CO}_{2}$ equivalent emission produced because of the flaring of natural gas is estimated to be 0.00398 $\mathrm{kg} / \mathrm{kwh}[9]$

\subsection{Well to Tank Emissions from Fossil Fuel}

We don't have much study done on the well to tank emission of fossil fuel for the Indian landscape. The OPGEE model 2.0 [10] can be used to model the emission from well to refinery gate. For our study we used the Well to Tank emission conversion data compiled by the UK government[11]. Although it is not accurate but it is a fair approximation as most of the fossil fuels used in India are sourced from gulf region which is almost equivalent to crude transportation distance in UK as well. The below table summarizes the GHS data.

Table 5 Well to tank emission of fossil fuel

\begin{tabular}{|l|c|c|}
\hline \multicolumn{1}{|c|}{ Fuel Type } & gCO $_{\mathbf{2 e}} /$ litre & gCO $_{\mathbf{2 e}} / \mathbf{k w h}$ \\
\hline Petrol & 593.44 & 66.134 \\
\hline Diesel & 610.15 & 61.272 \\
\hline
\end{tabular}

\subsection{Life cycle Emissions from Nuclear Fuel}

Nuclear power plants produce no greenhouse gas emissions during operation, and over the course of its life-cycle, nuclear produces some amount of carbon dioxide-equivalent emissions. As per IPCC study

[14] the average life-cycle carbon dioxide equivalent emissions from nuclear fuel is 12 $\mathrm{gCO}_{2} / \mathrm{kwh}$

\subsection{Efficiency Considerations}

Transmission and distribution loses of electric energy from power plants to charging stations also contribute to GHG emissions. In India transmission losses are high in comparison to 
world average [12]. The transmission loss in India stands at $22.77 \%$ [13] while the world average is around $8 \%$.

The charging of car battery also account for energy loss. The battery charging efficiency has a large variance with charging power available as well as the state of charge (SOC). The following table shows the charging efficiency against charging power. Source [14]

Table 6 Charging efficiency with respect to available power

\begin{tabular}{|l|c|c|c|c|c|}
\hline $\begin{array}{l}\text { Available } \\
\text { Power( kw) }\end{array}$ & 3 & 16 & 22 & 43 & 50 \\
\hline $\begin{array}{l}\text { Charging } \\
\text { efficiency @ } \\
23 \% \text { SOC }\end{array}$ & 85 & 84.6 & 90.6 & 90.6 & 91.4 \\
\hline
\end{tabular}

Because of the scarcity of public charging stations and the time availability, the likely charging pattern for passenger cars would be $90 \%$ home and $10 \%$ public DC charging stations. For Motorized Two Wheelers (MTW) it would be 100\% home [16]. The weighted average charging efficiency is $85.56 \%$ for passenger cars and $85 \%$ for MTW.

Table 7 Summary of GHG emission in gCO2e/kwh

\begin{tabular}{|l|c|c|c|c|c|c|}
\hline $\begin{array}{l}\text { Source of } \\
\text { emission }\end{array}$ & Coal & Lignite & Gas & Diesel & Nuclear & RES \\
\hline $\begin{array}{l}\text { Well to } \\
\text { Plant }\end{array}$ & 20 & $20^{*}$ & 3.98 & 61.27 & 12 & \\
\hline $\begin{array}{l}\text { Power } \\
\text { generation }\end{array}$ & 990 & 1360 & 460 & 640 & 0 & \\
\hline Total & 1010 & 1380 & 463.98 & 701.27 & 12 & 0 \\
\hline
\end{tabular}

${ }^{*}$ Calculated at the same level as coal.

The weighted average emission factor for power generation from all fuel sources in India can be approximated from the present grid mixture defined above is $596.824 \mathrm{gCO}_{2 \mathrm{e}} / \mathrm{kwh}$. There could be slight variation possible as the weighted average is calculated from capacity and not from actual generation mix.

To compensate for loss due to electricity transmission and battery charging, more fuel needs to be burned to deliver the power to wheels in an electric car or MTW. Considering the efficiency as factor for both transmission and battery charging as described above the total GHG emission is computed to be $903.21 \mathrm{gCO}_{2} / \mathrm{kwh}$.

\subsection{Manufacturing Emissions}

The biggest differentiator between ICEV and BEV manufacturing process emission is the battery manufacturing process. If we exclude the battery manufacturing emission there is not much difference between the emissions of ICEV and BEV manufacturing process. So for comparative emission study between ICEV and BEV only battery manufacturing emission is considered.

As per the IVL study battery manufacturing emission is between $61-106 \mathrm{kgCO}_{2} / \mathrm{kwh}$ with an upper bound of 146. [15]. The variation depends mainly on the power generation grid mix. Since $62.1 \%$ of energy comes from fossil fuel sources the higher bracket emission (106 $\mathrm{kgCO}_{2 \mathrm{e}} / \mathrm{kwh}$ ) is considered for our study.

The average usage of cars/MTW vary from 10-15 years in India. First hand users use the car for 6-8 years and second or third hand users generally keep it till 15 years. BEV car 
manufacturers promise a battery life up to $100,000 \mathrm{~km}$. So for this study a car lifetime of 8 years or $100,000 \mathrm{kms}$ is considered without battery replacement. For an average annual car mileage of $12199 \mathrm{kms}$ this translates to a life time of $97592 \mathrm{~km}$ without the need for battery replacement. Also the State of Health $(\mathrm{SOH})$ of battery degrades over the years. Efficiency is maximum when the battery is new and it degrades linearly with time. For efficiency computation average $\mathrm{SOH}$ at $4^{\text {th }}$ year is taken which is $91.9 \%$. Source [17].

So the effective available battery capacity $=$ Battery capacity when new $x \mathrm{SOH}$ at $4^{\text {th }}$ year

Table 8 Emissions attributed to battery life cycle

\begin{tabular}{|l|c|c|c|c|c|c|}
\hline \multicolumn{1}{|c|}{$\begin{array}{c}\text { Vehicle } \\
\text { type }\end{array}$} & $\begin{array}{c}\text { Battery } \\
\text { capacity } \\
\text { (kwh) }\end{array}$ & $\begin{array}{c}\text { Effective } \\
\text { battery } \\
\text { capacity } \\
\text { @91.9 } \\
\text { SOH }\end{array}$ & $\begin{array}{c}\text { Effective } \\
\text { Car } \\
\text { efficiency } \\
(\mathbf{k m} / \mathbf{k w h})\end{array}$ & $\begin{array}{c}\text { Battery } \\
\text { manufacturing } \\
\text { emission(kgCO }\end{array}$ & $\begin{array}{c}\text { Life mileage } \\
/ \text { battery pack }\end{array}$ & $\begin{array}{c}\text { Emission / km } \\
(\mathbf{g C O} / \mathbf{k m})\end{array}$ \\
\hline $\begin{array}{l}\text { Tata Tigor } \\
\text { EV }\end{array}$ & 21.5 & 19.76 & 9.01 & 2279 & $97592^{1}$ & 23.35 \\
\hline $\begin{array}{l}\text { Honda } \\
\text { dash }\end{array}$ & 1.344 & 1.235 & 40.62 & 142.46 & $78128^{2}$ & 1.82 \\
\hline
\end{tabular}

${ }^{1}$ With annual car mileage of $12199 \mathrm{~km}$

${ }^{2}$ With annual MTW mileage of $9766 \mathrm{~km}$

Now it is the time to compute the effective emission for all the vehicles under consideration All units in $\mathrm{gCO}_{2 \mathrm{e}} / \mathrm{km}$

Table 9 Stage emission of different vehicle types

\begin{tabular}{|l|c|c|c|c|c|c|}
\hline Vehicle Type & $\begin{array}{c}\text { ICE } \\
\text { cars - } \\
\text { Diesel }\end{array}$ & $\begin{array}{c}\text { BEV cars with ICE } \\
\text { - diesel for long } \\
\text { distance }\end{array}$ & $\begin{array}{c}\text { ICE cars } \\
\text { Petrol }\end{array}$ & $\begin{array}{c}\text { BEV cars with } \\
\text { ICE - petrol for } \\
\text { long distance }\end{array}$ & $\begin{array}{c}\text { ICE - } \\
\text { MTW }\end{array}$ & $\begin{array}{c}\text { BEV - } \\
\text { MTW }\end{array}$ \\
\hline $\begin{array}{l}\text { Operational } \\
\text { emission }\end{array}$ & 146.44 & 14.65 & 128.17 & 12.82 & 37.03 & 9.25 \\
\hline $\begin{array}{l}\text { Well to pump } \\
\text { emission for } \\
\text { fossil fuel }\end{array}$ & 33.45 & 3.35 & 32.6 & 3.26 & 9.42 & 2.35 \\
\hline $\begin{array}{l}\text { Well to pump } \\
\text { emission for } \\
\text { electricity }\end{array}$ & NA & 100.25 & NA & 100.25 & NA & 22.24 \\
\hline $\begin{array}{l}\text { Battery } \\
\text { emission }\end{array}$ & $\sim 0$ & 23.35 & $\sim 0$ & 23.35 & $\sim 0$ & 1.82 \\
\hline Total & 179.89 & 141.6 & 160.77 & 139.68 & 46.45 & 35.66 \\
\hline
\end{tabular}

The findings are plotted in the below graph figure 3

With all the operational emissions and upstream emissions considered the electric vehicles emit lesser Green House Gas (GHS) emissions per unit distance. The scenario can only get better from here as we move towards lesser GHS emitting power generation, improve transmission efficiency, recycling of battery etc. The government of India is already committed to move towards cleaner grid mix and by 2027 the coal and Lignite portion the generation mix will be cut down to $39 \%$ from the existing $55.3 \%$. 


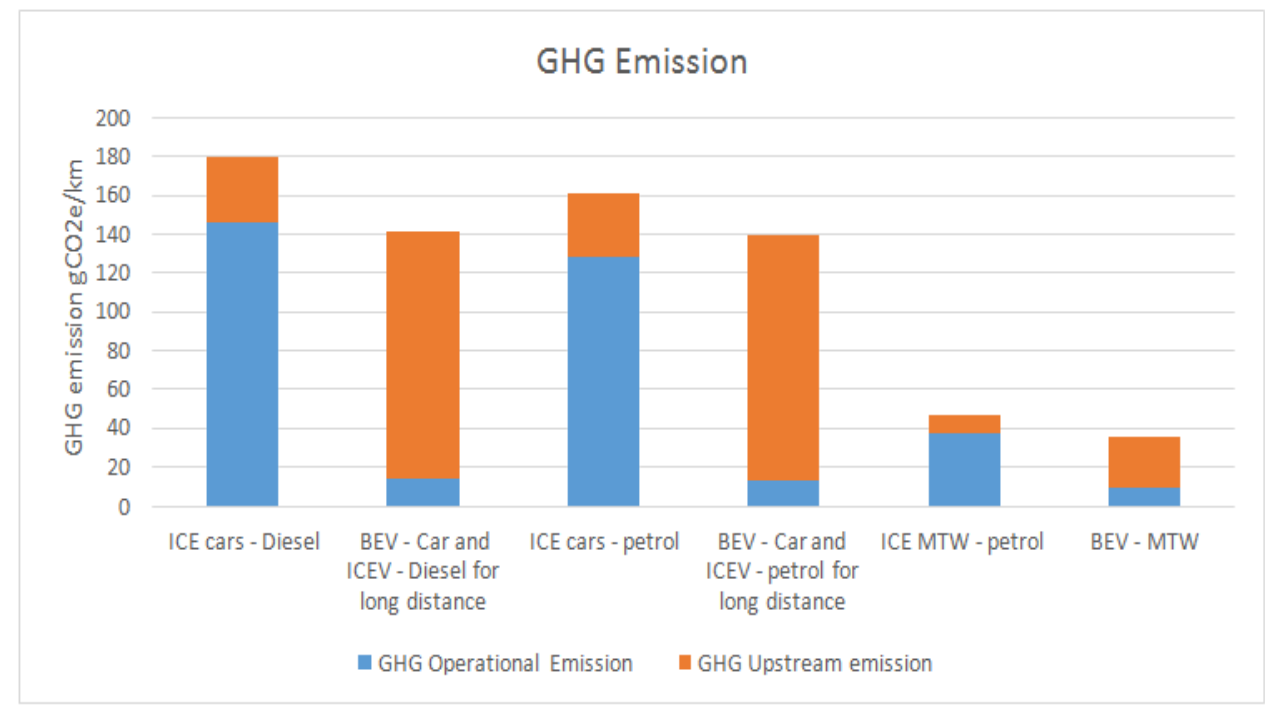

Figure $3 \mathrm{GHG}$ emission for different of vehicles split between operational emission and upstream emission

Renewable energy mix will be increased to $44 \%$ from the existing $23.8 \%$ [8]. Also transmission emission will also be reduced to $15 \%$.

March,2027

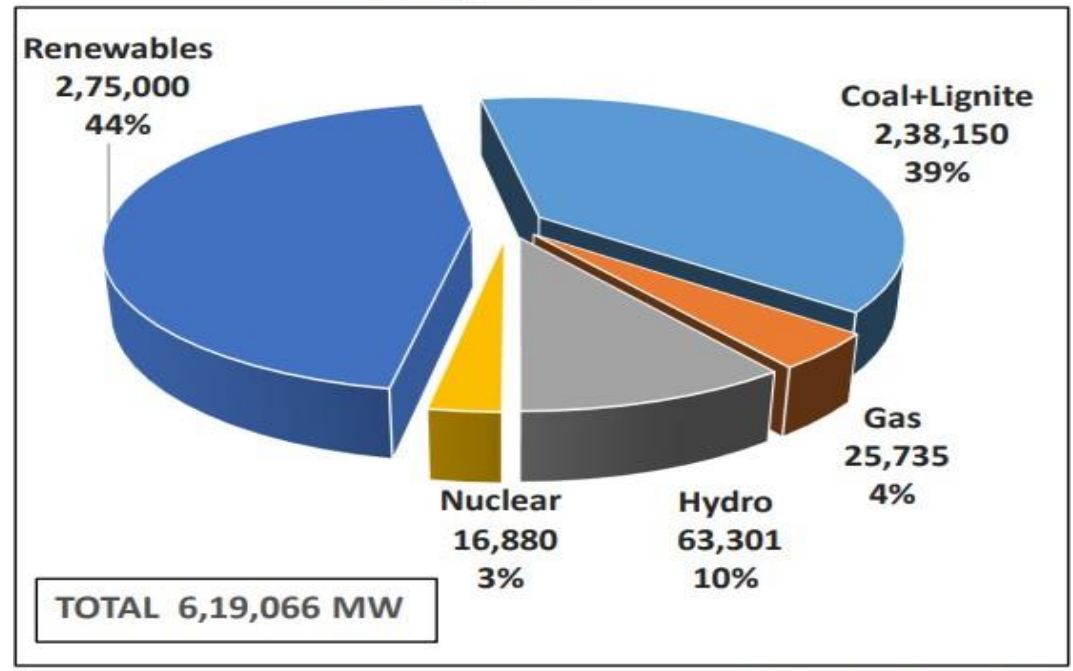

ALL FIGURES IN MW

Figure 42027 projection of energy mix. Source[8]

Just by considering the cleaner energy generation projection and transmission efficiency improvement by 2027 the GHG emission difference between ICEV and BEV is further reduced. 


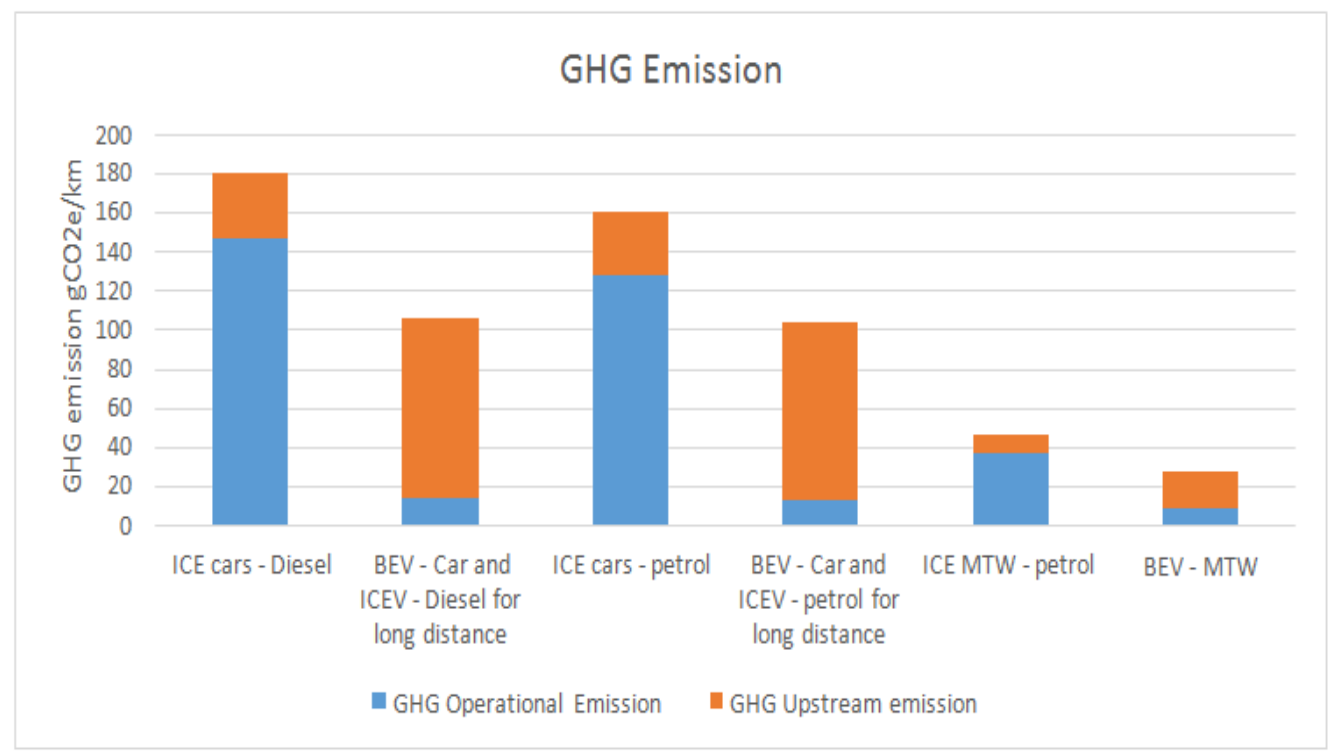

Figure 5 GHG emission difference outlook in 2027.

\section{CONCLUSION}

In this comparison study of emission difference between the conventional ICEV and BEV it is established that the even at the current state of energy grid mixture, transmission losses and battery manufacturing emissions BEF vehicles generate less GHG emissions per unit distance. This is $17.21 \%$ reduction in passenger cars and $23.23 \%$ in MTW. It translates to 5432.82 $\mathrm{KgCO}_{2 \mathrm{e}}$ in the 15 year life of the car. In the case of MTW it is $1580.63 \mathrm{KgCO}_{2 \mathrm{e}}$.

Further reduction in GHG emission is possible by increasing the percentage of cleaner fuels in the generation of electricity. By reducing the coal and lignite contribution to power generation by $16.3 \%$ and transmission losses by $7.27 \%$ saves $33.83 \mathrm{gCO}_{2 \mathrm{e}}$ from escaping to the atmosphere. Also we can consider the following to reduce the emissions further.

- Increasing the role of Renewable Energy Sources in power generation

- Power generation from Hydrogen fuel cell with Hydrogen sourced from Biomass. Biomass also sequester $\mathrm{CO}_{2}$ from the atmosphere aiding clean the atmosphere cause.

- Recycling and reuse of rechargeable batteries

- Recycling of vehicle materials.

India along with most countries is a signatory to the Parris accord for GHG emission reduction and is on the path to a better tomorrow.

\section{REFERENCES}

[1] Society of Automotive Engineers. "Utility Factor Definitions for Plug-In Hybrid Electric Vehicles Using 2001 U.S. DOT National Household Travel Survey Data," Hybrid Committee, J2841; March 2009.

[2] https://www.sciencedirect.com/science/article/pii/S0967070X17305310

[3] https://unepdtu.org/wp-content/uploads/2014/08/assessment-of-motor-vehicle-usecharacteristics- in-three-indian-cities.pdf

[4] https://www.epa.gov/energy/greenhouse-gas-equivalencies-calculator

[5] http://egazette.nic.in/WriteReadData/2015/163817.pdf 
Comparison of GHG Emissions between ICEV and BEV based on Indian Scenario

[6] https://powermin.nic.in/en/content/power-sector-glance-all-india

[7] https://www.researchgate.net/publication/267687877_Estimates_of_Emissions_from_Coal_Fi red_Ther mal_Power_Plants_in_India

[8] http://erpc.gov.in/wp-content/uploads/2018/06/carbon-emissions-from-power-sector7062018.pdf

[9] https://www.fipi.org.in/Reports/Relative\%20Environment\%20Economics\%20of\%20Natural\% 20Gas\%20a nd\%20Other\%20Fossil\%20Fuels.pdf

[10] http://pangea.stanford.edu/departments/ere/dropbox/EAO/OPGEE/OPGEE_v2.0.xlsm

[11] https://www.gov.uk/government/publications/greenhouse-gas-reporting-conversion- factors2020

[12] https://www.eia.gov/todayinenergy/detail.php?id=23452\#: :text=Despite\%20considerable\%2 0improve ment\%20since\%20the,does\%20not\%20reach\%20intended\%20customers.

[13] https://beeindia.gov.in/sites/default/files/Transmission\%20and\%20Distribution\%20Losses\%2 0by\%20CE A.pdf

[14] https://www.ipcc.ch/site/assets/uploads/2018/02/ipcc_wg3_ar5_chapter7.pdf https://www.mdpi.com/2032-6653/7/4/570/pdf

[15] https://www.ivl.se/download/18.14d7b12e16e3c5c36271070/1574923989017/C444.pdf

[16] https://evreporter.com/analysis-of-govt-charginginitiatives/\#: : :text=Charging\%20Pattern\%20for\%20Private\%20Vehicles\&text=Every\%20time $\%$ 20a\%20car\%20is, 100\%25\%20in\%20under\%207\%20hrs.

[17] https://www.geotab.com/blog/ev-battery-health/ 